https://doi.org/10.48009/1_iis_2010_417-422

\title{
THE DEBATE OF ONLINE COURSE QUALITY IN TRADITIONAL UNIVERSITIES: A CASE STUDY
}

Mohammad A. Rob, University of Houston, rob@uhcl.edu

\begin{abstract}
More and more traditional universities are going "fully" online with multiple courses and programs. What is the purpose of going online? Is it satisfying students or increasing enrollment, or just following others? In most cases, the decision makers are administrators rather than faculty members. What about the quality of online education? In many universities, the debate on the "quality" of online education over face-to-face classes has just begun as more and more courses and programs are becoming online. The online faculty members advocate that the quality is as good as the teacher - whether online or face-to-face. No one wishes to delve into the discussion of what a faculty member does in his/her physical or online classroom. There is an ongoing debate between the "academic freedom" of a faculty member and the "academic integrity" of a course. However, many faculty members question about the quality of online courses. This paper presents a case study of such a debate in a traditional university and presents the outcomes and recommendations of the findings, which might valuable to many academic institutions offering online education.
\end{abstract}

Keywords: online education, educational quality, online versus face-to-face.

\section{INTRODUCTION}

More and more "traditional" universities are going "fully" online with multiple courses and programs. What is the purpose of going online? Is it satisfying students or increasing enrollment, or just following others? What is the value added to the university in going online? Consider an example of our campus: The University of Houston-Clear Lake (UHCL). The enrollment number has not been going up, and as a matter of fact it has been going down or staying about the same over a decade. However, the cost of Volume XI, No. 1, 2010 running a university-wide online educational system is increasing every year. In most cases, the decision makers to go online are administrators rather than faculty members. The traditional classrooms that used to be scarce are becoming empty. However, the university is hiring more and more people to manage the online course delivery system. We all are going with the flow of technology or the bandwagon.

It is already established through many research studies that the primary reason students take online courses because it provides flexibility [1,2]. Students are customers and they need to be satisfied. Thus more and more courses are becoming online. The instructional technology teachers, who are pioneers of online education, and those who enjoy the flexibility of not coming to campus, are strong advocates of online education. One the other hand, the teachers who mainly teach in face-to-face classrooms are skeptical about online education; many question about the quality and integrity of online education. However, more and more teachers are teaching online courses; and many times there seems to be no coordination. In many traditional universities, the debate on the "quality" of online courses over face-to-faces classes has just begun as more and more courses and programs are becoming "fully" online.

\section{THE PROBLEM DEFINITION}

Over the past few years, several faculty members at UHCL have voiced concerns about online courses. Some instructors suggested that online courses should be marked in a special way in a transcript, others consider online degrees as equivalent of a paper mill degree offered by online universities. In the middle of Fall 2008, the Faculty Senate Curriculum and Instruction Committee made a point of discussion on the subject matter. Subsequently, a sub-committee was formed to look at the issues or concerns and asked to come up with a report. The 
committee consisted of faculty members teaching both online and face-to-face courses. Initially, the committee members were not clear about the specific issues to be discussed. However, debating through meetings and e-mail communications, the committee focused on the quality aspects of online education. So what is quality in online education? This paper is a reflection to finding an answer to this question.

\section{RESEARCH METHODOLOGY}

It is to be noted that the committee members were not chosen in a systematic way. It was in the form of a quick-pick by the committee chair, considering strong voices in favor or against the issue, and some are recommended by other committee members. The committee chairperson applied various methodologies in finding facts from various constituents of the university and discussing with the committee members. Some of the techniques include:

- One-to-one meetings with various administrative heads of the academic area, including provost, vice president of academic affairs, deans, associate deans, director of online education, director of institutional research, and etc.

- Sending e-mails to all business school faculty asking about their feelings on the quality of online education.

- Face-to-face meetings with some faculty members who teach online courses.

- Researching articles in journal and magazines that focus on quality of online education.

\section{Quality in Online Education}

Online education is now a reality due to the $21^{\text {st }}$ century technological innovation. It is a fairly new mechanism of teaching and learning compared to the traditional in-class or face-to-face method, and as such, it is open to discussion. Research shows that students take online courses mainly due to convenience, and over the years they are becoming increasingly satisfied with the quality, rigor, and value obtained from online courses $[1,2]$.
Is online education different from conventional or face-to-face education? The answer is yes. Educational institutions have been facing a daunting task of keeping pace with the technology. There is also a concern whether online courses provide the same quality of learning as face-to-face sessions. Many universities have looked into the process of improving the quality of online courses and thus increasing student satisfaction. They have also developed policies, standards, guidelines, and/or benchmarks that provide quality assurance for online courses [3-9]. A study by the Institute for Higher Education Policy reports [4]:

"This study identifies 24 benchmarks considered essential to ensuring excellence in Internet-based distance learning, as used by the following six institutions which are leaders in distance education: Brevard Community College (Florida); Regents College (New York); University of Illinois at Urbana-Champaign; University of Maryland University College; Utah State University; and Weber State University (Utah). The benchmarks are divided into seven categories: (1) institutional support; (2) course development; (3) teaching/learning; (4) course structure; (5) student support; (6) faculty support; and (7) evaluation and assessment. The study seeks to ascertain the degree to which the benchmarks are actually incorporated in the policies and practices of the institutions, and how important the benchmarks are to faculty, administrators, and students."

Accreditation agencies such as SACS, AACSB, and ABET have also been looking at the quality aspects of online education [10-13]. Although, there are no specific standards set for online education, it is specified that [11]:

"Institutions that grant certificates are responsible to show consistent level of academic rigor throughout the institution, and technology is an irrelevant variable." 
Thus, it is the responsibility of the universities to adapt processes that define what makes an online education one of quality. Nevertheless, all accreditation agencies promote the Principles of Good Practice in online education. The Instructional Technology Council outlines the best practices an institution can adapt to assure quality in online education $[12,13]$. It includes practices in areas of institutional commitment and support, curriculum and instruction, faculty support, student support, as well as assessment and evaluation.

\section{Online Education Status at UHCL}

UHCL is not at the forefront of online education as compared to many other institutions - not in terms of quantity or quality. Currently, there are five "fully" online graduate degree programs and several certificate programs, as well as many online courses in the various schools.

To the best of our knowledge, there is no active policy on online education at UHCL, although there has been a policy on distance education in the Faculty Handbook, which was developed on 03/09/2000 and expires on 03/09/2010. Although the policy statements address some of the important benchmarks discussed before, there is no evidence that they are practiced in an organized way by any school, program or faculty.

Until recently, there was no central office or committee to monitor the progression of online education throughout the campus. However, recently, the situation has been evolving and starting last year, the university hired a full-time director for distance or online education to coordinate the efforts of online education throughout the campus. Subsequently, there have been some dialogues among various educational components within the campus.

It seems that the Senate Research committee, and the Shared Governance committee, such as Facilities and Resources Committee, as well as the University Computing Facility are involved in various aspects of online education. It is not clear how the university

Volume XI, No. 1, 2010 and various schools are preparing to address quality assurance requirements of SACS, AACSB, and ABET, specifically for the online programs and courses.

\section{The Debate among the UHCL Faculty}

At UHCL the debate on the "quality" of online education over face-to-face courses has just begun as more and more courses and programs are becoming online. The proponents say that the quality is as good as the teacher - whether online or face-to-face. No one wishes to delve into the discussion of what a faculty member is doing in his/her physical or online classroom. However, many faculty members question about the quality of online courses, especially the integrity of online tests, quizzes, and etc. Thus there is an ongoing debate between the "academic freedom" of a faculty member and the "academic integrity" of a course.

Cheating in the classroom has always been a concern in the academic environment. Many instructors have concerns about online tests, quizzes or activities that measure the individual student's merit. When a student is online in a distant place, no one knows with certainty who is in actuality taking the test or completing the project. Obviously, the mode of online teaching opens the door of cheating more than the traditional classroom method. When the integrity is a concern, it follows that the quality is a concern. Online plagiarism is the most significant concern in online education as voiced by many researchers [ $[14$, $15]$.

Contrary to that, in writing about "Maintaining Academic Integrity in Online Education," Michael Heberling, President of Baker College Center for Graduate Studies, wrote [14]:

"Online education has come under a great deal of scrutiny over the issue of academic integrity. It is assumed that cheating and plagiarism are a greater problem in online than in a traditional class. In reality, maintaining academic integrity is equally a challenge in both delivery modes. However, by the very nature of online education, a

Issues in Information Systems 
case can be made that it is more conducive to both detecting and combating plagiarism than is a traditional class."

The question arises whether ample mechanisms are in place to combat plagiarism in online courses at UHCL. Some UHCL faculty members contend that:

"Online testing can be considered as a method of rewarding the dishonest and penalizing the honest."

Even companies such as Microsoft, Oracle and Novell that provide professional certifications require physical presence of an examinee in a supervised place. Educational institutions that award degree certificates have a responsibility to have quality control processes in place for the benefit of the students.

\section{RESULTS}

The results of the finding can be considered as a form of report and recommendations as discussed below.

1. Policy Manual for Online Education: The University updates its current distance education policy (found in the Faculty Handbook) with a "Policy Manual for Online Education," which should reflect the quality control standards and benchmarks proposed by accreditation and other education agencies and adapted by many universities in the world. It must reflect quality-control measures required by SACS, AACSB and ABET, which are accreditation agencies for UHCL [12]. It must define various modes of online education as well as the quality control measures in those modes of education.

2. University-Level Committee for Quality Assurance: In developing the policy manual, a university-wide committee should be formed with members from various constituencies of the campus that are responsible for developing and delivering

Volume XI, No. 1, 2010 online education. This committee will not only develop the policy manual but will also monitor quality assurance of online education on an ongoing basis. The following is a proposed list of membership in the committee:

- A members from the Provost's office - Director of distance learning

- A member from the University Computing Facility

- A member from the Senate Curriculum and Teaching Committee

- A member for SACS compliance Director of Institutional Research

- A member for AACSB compliance - Associate Dean in the School of Business

- A member for ABET compliance Associate Dean of SCE

- A faculty representative from each school - Coordinator of schoolwide committee as mentioned below

- Other stakeholders directly involved in online education

3. School-wide Committee: Each school must have a committee with representatives from various programs to oversee all online course development as well as monitor and control quality assurance processes. The school committees will coordinate its activities with the university-wide committee.

4. Program-Level Committee: Programs that already have online courses or aspire to have online courses should have a committee to recommend which courses should be in what media, i.e., fully online courses, partially online or web-enhanced courses, and faceto-face courses. The committee will coordinate its activities with the school-wide committee.

5. Individual Faculty: A faculty member teaching an online course will coordinate Issues in Information Systems 
with the program-level committee to determine what instructional strategy he/she will employ in teaching his/her course.

\section{CONCLUSION}

The debate on the "quality" of online education over face-to-face classes among various faculty members at the University of Houston-Clear Lake is common to many traditional colleges and universities. These institutions need to get ready to address the quality assurance requirements of online courses and programs to the accreditation agencies. The findings of this paper as well as the recommendations can be extremely valuable in improving the quality of online education as well as addressing that to the accreditation agencies.

\section{REFERENCES}

1. Graduate Business Students' Perceptions of Online Learning: A Five Year Comparison, The Delta Pi Epsilon Journal, Volume L, No. 3, 2008.

2. A comparison of student perceptions regarding online learning versus traditional classroom learning, Journal of Computing Sciences in Colleges, Volume 25, Issue 1, October 2009.

3. The Quality Dilemma in Online Education, Author: Nancy K. Parker, The Theory and Practice of Online Learning, Edited by Terry Anderson. Athabasca University Press, Edmonton, Canada.

4. Quality on the Line: Benchmarks for Success in Internet-Based Distance Education, Author: R. Phipps and J. Merisotis, Report from the Institute for Higher Education Policy, http://www.ihep.com.

5. Quality Standards in e-Learning: A matrix of analysis, Author: Jia Frydenberg, Irvine Distance Learning Center, University of California, http://www.irrodl.org/index.php/irrodl/articl e/viewArticle/109/189

Volume XI, No. 1, 2010
6. Quality Assurance for Online Courses: Implementing Policy at RMIT, The Technology Source Archives at the University of North Carolina, http://www.technologysource.org/article/qua lity assurance for_online courses/

7. Quality Assurance for Online Nursing Courses, Author: Barbara B. Little, Journal of Nursing Education, Vol. 48, No. 7, 2009.

8. Exploring Benchmarks and Standards for Assuring Quality Online Teaching and Learning in Higher Education, http://elrond.scca.ecu.edu.au/oliver/2003/odl aa.pdf

9. Quality Assurance for Online Courses: From Policy to process to Improvement? Carmel McNaught, RMIT University, Australia. http://www.ascilite.org.au/conferences/melb ourne01/pdf/papers/mcnaughtc.pdf

10. The Principles of Accreditation: Foundations for Quality Enhancement, 2008 Edition, Southern Association of Colleges and Schools http://www.sacscoc.org/pdf/2008Principleso fAccreditation.pdf

11. Emerging Issues in Quality Assurance for Online Courses, Association to Advance Collegiate Schools of Business (AACSB), International 2004 Distance Learning Conference, Houston, Texas. http://www.aacsb.edu/

12. Best Practice Strategies to Promote Academic Integrity in Online Education, Version 2.0, June 2009, http://wiche.edu/attachment_library/Student _Authentication/BestPractices.pdf

13. Assuring Quality in Distance Learning, Council for Higher Education Accreditation, http://www.chea.org/pdf/HED_Apr1998.pdf

14. Maintaining Academic Integrity in Online Education, Author: Michael Heberling, President, Baker College Center for Graduate Studies, http://www.westga.edu/ distance/ojdla/sprin g2002/heberling51.html

Issues in Information Systems 
15. Academic dishonesty in graduate business programs: Prevalence, causes, and proposed
Actions, Academy of Management Learning \& Education, Vol. 5, No. 3, 2006. 